\title{
Penguatan Proses Kognitif Melalui Pendekatan Student Centered Learning (SCL) Pada Materi Perencanaan dan Pengembangan Tes Hasil Belajar Pendidikan Agama Islam
}

\author{
Abdul Haris ${ }^{1}$ \\ email: a hrys@yahoo.go.id
}

\begin{abstract}
Abstrak: Penguatan proses kognitif melalui Pendekatan Student Centered Learning (SCL) pada Materi Perencanaan dan Pengembangan Tes Hasil Belajar Pendidikan Agama Islam merupakan kegiatan tindak lanjut atas keadaan mengenai kemampuan mahasiswa Prodi Pendidikan Agama Islam (PAI) dalam memahami Materi Perencanaan dan Pengembangan Tes Hasil Belajar Pendidikan Agama Islam masih rendah. Keadaan ini ditengarai akibat mahasiswa belum menguasai kemampuan prasyarat, prosedural, dan kemampuan kognitif yang diperlukan dalam merencanakan dan mengembangkan tes hasil belajar Pendidikan Agama Islam. Penerapan Student Centered Learning (SCL) diharapkan dapat menjadi pendekatan pembelajaran yang inovatif yang dapat memberi penguatan proses kognitif bagi mahasiswa untuk mengembangkan keterampilan ilmiah secara maksimal dalam merencanakan dan mengembangkan tes hasil belajar Pendidikan Agama Islam.
\end{abstract}

Berdasarkan hasil instruksional menggunakan Pembelajaran Berbasis Masalah sebagai bagian SCL pada Materi Perencanaan dan Pengembangan Tes Hasil Belajar Pendidikan Agama Islam dalam penelitian ini menunjukkan bahwa: a) Teknik instruksional SCL khususnya pembelajaran berbasis masalah dapat diintegrasikan ke dalam kegiatan perencanaan dan pengembangan tes hasil belajar dengan melibatkan berbagai atribut yang dapat menguatkan proses kognitif; b) Atribut-atribut softs skills mahasiswa yang bersesuaian dengan atribut-atribut SCL yang diintegrasikan dalam proses kognitif mahasiswa pada kegiatan perencanaan dan pengembangan tes hasil belajar adalah: berfikir kritis dan analitis; kerjasama, diskusi, kemampuan dokumentasi, presentasi, merupakan penekanan dari pemecahan masalah; c) Implementasi SCL dalam kegiatan perencanaan dan pengembangan tes hasil belajar berdampak pada penguatan proses kognitif mahasiswa dalam perencanaan dan pengembangan tes hasil belajar; dan d) Implementasi SCL dalam perencanaan dan pengembangan tes hasil belajar cukup efisien digunakan, karena mahasiswa mampu mengembangan kemampuan proses kognitif sebagai bagian pengetahuan metakognitf yang diperlukan dalam kegiatan pembelajaran bermakna.

Kata Kunci: Proses Kognitif, Student Centered Learning (SCL), Perencanaan dan Pengembangan Tes Hasil Belajar, Pendidikan Agama Islam 


\section{Pendahuluan}

Pendidikan sebagaimana dalam Undang-Undang Sistem Pendidikan Nasional nomor 20 tahun 2003 dinyatakan sebagai usaha sadar dan terencana untuk mewujudkan suasana belajar dan proses pembelajaran agar peserta didik secara aktif mengembangkan potensi dirinya untuk memiliki kekuatan spiritual keagamaan, pengendalian diri, kepribadian, kecerdasan, akhlak mulia, serta keterampilan yang diperlukan dirinya, masyarakat, bangsa dan negara. Dengan uraian demikian, maka siswa peserta didik tidak hanya terbatas sebagai peserta yang melakukan proses belajar melainkan lebih sebagai peserta yang harus memiliki kemampuan dasar yang diperlukan dalam proses kognitifnya.

Untuk mengembangkan potensi dirinya secara aktif, siswa sebagai peserta didik harus memiliki pengetahuan (metekognitif) yang cukup sebagai modal awal atau bahan dasar yang sangat berperan dalam berinteraksi selain kepemilikan pengetahuan semata sehingga dapat menandai kepemilikan sumberdaya manusia yang diharapkan.

Sumber daya manusia yang berkualitas tidak saja diukur dari kepemilikan pengetahuan semata, tetapi lebih kepada outcome, sebagai bentuk kemampuan yang berkesinambungan dalam meningkatkan mutu hidup.

Secara operasional, penentuan kualitas sumberdaya manusia tidaklah sederhana sebagaimana konsep sumber daya manusia yang diharapkan. Dalam kegiatan pendidikan dan/atau pembelajaran yang berpusat pada siswa, tugas penetapan nilai sebagai parameter keberhasilan siswa merupakan salah satu kegiatan evaluasi yang dilakukan guru dan memiliki tingkat kesulitan tertentu.

Kegiatan evaluasi merupakan rangkaian kegiatan penilaian, pengukuran, dan tes. Evaluasi sebagai suatu proses yang sistematis dan berkelanjutan untuk menentukan kualitas dari suatu objek tertentu, berdasarkan pertimbangan dan kriteria tertentu dalam rangka pembuatan keputusan. Penilaian adalah suatu proses atau kegiatan yang sistematis dan berkesinambungan untuk mengumpulkan informasi tentang proses dan hasil belajar siswa dalam rangka membuat keputusan-keputusan berdasarkan kriteria dan pertimbangan tertentu.

Tes sebagai alat evaluasi yang digunakan untuk mengukur pengetahuan atau penguasaan pengetahuan tertentu terhadap suatu materi tertentu. Penggunaan tes merupakan suatu teknik atau cara yang digunakan dalam rangka melaksanakan kegiatan pengukuran (evaluasi). Dalam tes terdapat berbagai pertanyaan, pernyataan, dan/ atau serangkaian tugas yang harus dikerjakan oleh siswa. Dengan cara demikian ini, maka dapat diketahui sejauh mana perubahan perilaku sebagaimana tujuan pembelajaran yang ingin dicapai oleh para siswa sebagai peserta belajar. Dalam kegiatan evaluasi hasil belajar Pendidikan Agama Islam, diperlukan alat ukur yang valid dan reliable. Untuk memperoleh alat ukur dengan persyaratan demikian, maka suatu alat ukur harus dikembangkan melalui perencanaan yang matang.

Mahasiswa Program Studi Pendidikan Agama Islam sebagai calon guru Pendidikan Agama Islam (PAI) perlu memiliki kemampuan dalam merencanakan dan mengembangkan tes hasil belajar Pendidikan Agama Islam.

Kemampuan merencanakan dan mengembangkan tes hasil belajar bagi mahasiswa Program Studi Pendidikan Agama Islam (PAI) sebagai calon guru PAI disajikan melalui Pendekatan Student Centered Learning (SCL) sebagaimana 
Kurikulum Pendidikan Tinggi pada matakuliah Evaluasi Hasil Pembelajaran Pendidikan Agama Islam.

Untuk memperoleh kemampuan dalam perencanaan dan pengembangan tes hasil belajar PAI, mahasiswa sebagai calon guru diharapkan memiliki kemampuan dalam mengelola aspek kemampuan yang diharapkan dicapai oleh siswa sebagai peserta tes.

Berdasarkan pengalaman peneliti yang sekaligus sebagai dosen pengampu mata kuliah Evaluasi Pembelajaran PAI pada Prodi PAI STAI Al-Amin Dompu, bahwa sebagian besar mahasiwa peserta matakuliah Evaluasi Pembelajaran PAI menghadapi kesulitan dalam perencanaan dan pengembangan tes hasil belajar PAI.

Berdasarkan pengalaman di atas, maka akan dilakukan penelitian Penguatan Proses Kognitif Melalui Pendekatan Student Centered Learning (SCL) Pada Materi Perencanaan dan Pengembangan Tes Hasil Belajar Pendidikan Agama Islam

\section{Proses Kognitif}

Dalam pandangan ahli kognitif, tingkah laku manusia yang tampak tak dapat diukur dan diterangkan tanpa melibatkan proses kognitif. Dalam perspektif ini, belajar pada dasarnya adalah peristiwa mental/kognitif, bukan peristiwa behavioral yang bersifat jasmaniah. Dengan demikian maka dapat dipahami bahwa peristiwa behavioral merupakan pengejawantahan dari hasil proses kognitif.

Istilah kognitif berasal dari kata Latin cognoscere yang artinya mengetahui (to know). Aspek kognitif selalu berfokus pada cara memperoleh suatu pemahaman tentang dirinya serta lingkungannya, dan bagaimana dengan kesadarannya, ia bertindak terhadap lingkungannya. Proses belajar dalam kognitivisme tidak lagi dipandang sebagai pembentukan prilaku yang diperoleh dari pengulangan hubungan stimulus-respons secara kaku, dan adanya penguatanpenguatan, tetapi mencakup fungsi pengalaman perseptual dan proses kognitif yang meliputi ingatan, lupa, pengolahan informasi dan sebagainya. Melalui proses berpikir, maka stimulus-stimulus yang datang dari luar diatur, diolah, kemudian disesuaikan dengan struktur kognitif yang dimilikinya sehingga prosesnya menjadi kompleks, dan kemudian terjadilah perubahan perilaku, pola pikir, dan pemahaman tentang sesuatu objek tertentu.

Salah satu teori belajar yang menekankan proses kognitif adalah sebagaimana teori kognitif Piaget, yakni proses belajar terjadi dengan melibatkan dua proses dalam dirinya, yaitu proses organisasi informasi dan proses adaptasi (Baharuddin \& Wayuni (2007: 118-119).

Proses organisasi merupakan proses yang terjadi pada saat menghubungkan informasi (pengetahuan, fakta, dll) yang diterimanya dengan struktur-struktur pengetahuan yang sudah disimpan (skemata) atau sudah ada sebelumnya dalam otak.

Proses adaptasi dimaksud sebagai proses yang meliputi penggabungan atau pengintegrasian pengetahuan yang diterima dan mengubah struktur pengetahuan yang dimiliki dengan struktur pengetahuan baru, sehingga akan terjadi keseimbangan. Dalam proses adaptasi, Piaget mengemukakan empat dasar sebagai rangkaian komponen yang mensyarati proses adaptasi yakni skemata, asimilasi, 
akomodasi, dan keseimbangan (equilibrium). Skemata adalah struktur mental seseorang, dimana manusia selalu berusaha menyesuaikan diri dengan lingkunganya. Manusia cenderung mengorganisasikan tingkah laku dan pikirannya. Asimilasi merupakan penyerapan informasi baru. Dalam hal ini ada penyesuaian diri dengan keadaan lingkungannya. Akomodasi sebagai proses penggabungan informasi baru dengan skemata sehingga terbentuk keseimbangan baru (equilibrium)

Berdasarkan hal tersebut, Piaget, menyatakan bahwa pengetahuan dibentuk melalui dua proses yaitu asimilasi dan akomodasi terhadap skema pengetahuan seseorang.

\section{Pendekatan Student Centered Learning (SCL) dalam Pembelajaran Berbasis Masalah}

Untuk menuntun partisipasi aktif mahasiswa melalui pendekatan Student Centered Learning perlu memiliki langkah-langkah yang berfungsi sebagai sumber informasi bagi mahasiswa sehingga informasi itu dapat ditelaah serta terjadi proses pemecahan masalah. Hal ini sebagaimana dinyatakan Tina Afiatin (2009) bahwa pembelajaran yang bermakna dengan pendekatan yang berpusat pada siswa harus mampu menuntut partisipasi aktif dari siswa, seperti; a) Information Sharing dengan cara brainstorming, kooperatif, kolaboratif, diskusi kelompok, panel discussion, simposium, dan seminar; b) belajar dari pengalaman (Experience Based) dengan cara simulasi, roleplay, permainan, dan kelompok temu; dan c) pembelajaran melalui pemecahan masalah (Problem Solving Based) dengan cara studi kasus, tutorial, lokakarya.

Dengan pengelolaan pembelajaran yang baik melalui pembelajaran Student Centered Learning, maka pembelajaran yang dilaksanakan harus memenuhi prinsip-prinsip pembelajaran Student Centered Learning, sehingga mahasiswa sebagai peserta belajar mampu berperan baik secara perorangan maupun dalam kelompok.

Pembelajaran berbasis masalah sebagai salah satu model pembelajaran Student Centered Learning dapat menjadi alternatif yang dapat menjadikan mahasiswa melakukan belajar dengan menggali atau mencari informasi (inquiry), dan menggunakan informasi yang diperolehnya untuk memecahkan masalah faktual yang sedang dihadapi. Dengan demikian, maka mahasiswa dapat menganalisis strategi pemecahan masalah yang sedang dihadapinya.

Dengan metode ini dosen harus mampu bertindak sebagai fasilitator dan motivator sehingga dapat merangsang tugas belajar dengan berbagai alternatif metode penyelesaian masalah yang dihadapi mahasiswanya.

Sebagai sebuah pendekatan proses pembelajaran yang memiliki potensi menyeimbangkan kemampuan kognitif, motorik, dan emosi, Student Centered Learning memiliki prinsip-prinsip membentuk kemampuan/keadaan, yakni; tanggung jawab, peranserta/ keaktifan (mandiri/ berkelompok), adil, berfikir kritis dan kreatif, komunikatif, kerjasama, dan integritas bagi peserta didik.

\section{Perencanaan dan Pengembangan Tes Hasil Belajar Pendidikan Agama Islam}

Dalam merencanakan tes hasil belajar perlu mempertimbangkan berbagai hal. Hal-hal yang perlu dipertimbangkan dalam merencanakan tes; 1) Pengambilan sampel dan pemilihan butir soal; 2) Aspek yang akan diuji; 3) Tipe tes yang akan 
digunakan; 4) Format butir soal; 5) Jumlah butir soal; dan 6) Distribusi tingkat kesukaran butir soal ( $25 \%$ mudah, 50\% sedang, $25 \%$ sukar).

Untuk mengembangkan tes dapat diikuti langkah-langkah sebagai berikut: 1)

Menyusun kisi-kisi tes; 2) Menulis soal; 3) Menelaah soal; 4) Mengujicoba soal;

5) Menganalisis butir soal; 6) Memperbaiki tes; 7) Merakit tes; 8)

Melaksanakan tes; dan 9) Menafsirkan hasil tes.

Aspek yang Diuji

Untuk mengklasifikasi aspek yang akan diuji, maka dapat digunakan taksonomi Bloom yang me;iputi 3 aspek, yakni; 1) Cognitive Domain (Ranah Kognitif), yang berisi perilaku-perilaku yang menekankan aspek intelektual, seperti pengetahuan, pemahaman, aplikasi, keterampilan berpikir, dan mencipta, 2) Affective Domain (Ranah Afektif) berisi perilaku-perilaku yang menekankan aspek perasaan dan emosi, seperti minat, sikap, apresiasi, dan cara penyesuaian diri, dan 3) Psychomotor Domain (Ranah Psikomotor) berisi perilaku-perilaku yang menekankan aspek keterampilan motorik seperti tulisan tangan, mengetik, berenang, dan mengoperasikan mesin (Arikunto S., 2009: 117).

Bloom mengklasifikasi ranah kognitif menjadi enam (6) komponen, yakni: 1) Pengetahuan (Knowledge), kemampuan untuk mengenali dan mengingat istilahistilah, fakta-fakta, konsep, definisi, nama, rumusan teori, gagasan, pola, urutan metodologi, dan prinsip dasar (Abdullah Tsani, 2011: 6). Pengetahuan meliputi proses mengidentifikasi, menyatakan, mengingat, menyebutkan, memberi nama, menandai, memilih, dan memberi definisi yang di dalamnya meliputi ingatan akan hal-hal yang pernah dipelajari dan disimpan dalam ingatan (Yamin, Martiis, 2005: 45-46); 2) Pemahaman (Comprehension), merupakan kemampuan untuk membaca dan memahami gambaran, laporan, tabel, diagram, arahan, dan peraturan. Pemahaman merupakan proses menjelaskan, memberi contoh, menguraikan, menerjemah, menentukan, menafsirkan, merumuskan, merangkum, memperkirakan dan memahami setiap hal yang telah dicerna dalam proses pengetahuan; 3) Aplikasi (Apply), merupakan kemampuan menerapkan suatu konsep, prinsip, dan metode pada suatu masalah yang kongkrit dan baru. Aplikasi merupakan proses menerapkan, memperhitungkan, membuktikan, menunjukkan, dan menghasilkan suatu konsep-konsep yang belum pernah ditemui dengan jalan memahami konsep tersebut; 4) Analisis (Analysis), merupakan kemampuan untuk merinci suatu kesatuan ke dalam bagian-bagian, sehingga struktur keseluruhan atau organisasinya dapat dipahami dengan baik. Analisis merupakan proses mengenali, membedakan, menyimpulkan dan menganalisa suatu masalah yang kompleks menjadi sub-sub bagian agar masalah tersebut dapat dipahami dengan baik; 5) Evaluasi (Evaluation), merupakan suatu kemampuan memberi penilaian terhadap solusi, gagasan, dan metodologi berdasarkan kriteria dan standar tertentu untuk menentukan nilai; dan 6) Mencita, merupakan proses menyusun elemen-elemen menjadi sebuah kesatuan yang koheren dan fungsional yang pada akhirnya dapat menghasilkan sebuah produk baru yang belum pernah ada sebelumnya. (Anderson, L.W., dan Krathwohl, D.R. 2001). 
Tabel 1 Taksonomi Anderson dan Krathwohl (2001)

\begin{tabular}{|c|c|c|}
\hline Tingkatan & Berpikir Tingkat Tinggi & $\begin{array}{c}\text { Komunikasi } \\
\text { (communication } \\
\text { spectrum) }\end{array}$ \\
\hline $\begin{array}{l}\text { Menciptakan } \\
\text { (Creating) }\end{array}$ & $\begin{array}{l}\text { Menggeneralisasikan } \\
\text { (generating), merancang } \\
\text { (designing), memproduksi } \\
\text { (producing), merencanakan } \\
\text { kembali (devising) }\end{array}$ & $\begin{array}{l}\text { Negosiasi (negotiating), } \\
\text { memoderatori } \\
\text { (moderating), } \\
\text { kolaborasi } \\
\text { (collaborating) }\end{array}$ \\
\hline $\begin{array}{l}\text { Mengevaluasi } \\
\text { (Evaluating) }\end{array}$ & $\begin{array}{l}\text { Mengecek (checking), } \\
\text { mengkritisi (critiquing), } \\
\text { hipotesa (hypothesising), } \\
\text { eksperimen } \\
\text { (experimenting) }\end{array}$ & $\begin{array}{l}\text { Bertemu dengan } \\
\text { jaringan/ } \\
\text { mendiskusikan (net } \\
\text { meeting), berkomentar } \\
\text { (commenting), berdebat } \\
\text { (debating) }\end{array}$ \\
\hline $\begin{array}{l}\text { Menganalisis } \\
\text { (Analyzing) }\end{array}$ & $\begin{array}{l}\text { Memberi atribut } \\
\text { (attributeing), } \\
\text { mengorganisasikan } \\
\text { (organizing), } \\
\text { mengintegrasikan } \\
\text { (integrating), mensahihkan } \\
\text { (validating) }\end{array}$ & $\begin{array}{l}\text { Menanyakan } \\
\text { (Questioning), } \\
\text { meninjau ulang } \\
\text { (reviewing) }\end{array}$ \\
\hline $\begin{array}{l}\text { Menerapkan } \\
\text { (Applying) }\end{array}$ & $\begin{array}{l}\text { Menjalankan prosedur } \\
\text { (executing), } \\
\text { mengimplementasikan } \\
\text { (implementing), } \\
\text { menyebarkan (sharing), }\end{array}$ & $\begin{array}{l}\text { Posting, blogging, } \\
\text { menjawab } \\
\text { (replying) }\end{array}$ \\
\hline $\begin{array}{l}\text { Memahami/ } \\
\text { mengerti } \\
\text { (Understanding) }\end{array}$ & $\begin{array}{l}\text { Mengklasifikasikan } \\
\text { (classification), } \\
\text { membandingkan } \\
\text { (comparing), } \\
\text { menginterpretasikan } \\
\text { (interpreting), berpendapat } \\
\text { (inferring) }\end{array}$ & $\begin{array}{l}\text { Bercakap (chatting), } \\
\text { menyumbang } \\
\text { (contributing), } \\
\text { networking, }\end{array}$ \\
\hline $\begin{array}{l}\text { Mengingat } \\
\text { (Remembering) }\end{array}$ & $\begin{array}{l}\text { Mengenali (recognition), } \\
\text { memanggil kembali } \\
\text { (recalling), } \\
\text { mendeskripsikan } \\
\text { (describing), } \\
\text { mengidentifikasi } \\
\text { (identifying) }\end{array}$ & $\begin{array}{l}\text { Menulis teks (texting), } \\
\text { mengirim pesan singkat } \\
\text { (instant messaging), } \\
\text { berbicara (twittering) }\end{array}$ \\
\hline
\end{tabular}




\section{Dimensi Pengetahuan}

Pengetahuan faktual meliputi elemen-elemen dasar yang digunakan dalam menjelaskan, memahami, dan secara sistematis menata disiplin ilmu tertentu. Elemen-elemen dasar ini biasanya harus diketahui siswa jika mereka akan mempelajari suatu disiplin ilmu atau menyelesaikan masalah dalam disiplin ilmu tertentu. Pengetahuan faktual terbagi menjadi dua subjenis yaitu: (1) pengetahuan tentang terminologi; dan (2) pengetahuan tentang detail-detail dan elemen-elemen yang spesifik. Pengetahuan terminologi melipui pengetahuan tentang label dan simbol verbal dan nonverbal (kata, angka, tanda, gambar). Setiap materi kajian mempunyai banyak label dan simbol, baik verbal maupun nonverbal, yang merujuk pada makna-makna tertentu. Label dan simbol ini merupakan bahasa dasar dalam suatu disiplin ilmu.

Pengetahuan konseptual mencakup pengetahuan tentang kategori, klasifikasi, dan hubungan antara dua atau lebih kategori pengetahuan yang lebih kompleks dan tertata. Pengetahuan konseptual meliputi skema, model, mental, dan teori yang mempresentasikan pengetahuan manusia tentang bagaimana suatu materi kajian ditata dan distrukturkan, bagaimana bagian-bagian informasi saling berkaitan secara sistematis, dan bagaimana bagian-bagian ini berfungsi bersama. Pengetahuan ini terdiri atas subjenis yaitu: (1) pengetahuan tentang klasifikasi dan kategori; (2) pengetahuan tentang prinsip dan generalisasi; dan (3) pengetahuan tentang teori, model, dan struktur.

Pengetahuan prosedural adalah pengetahuan tentang cara melakukan sesuatu. Pengetahuan ini mencakup pengetahuan tentang keterampilan, algoritma, teknik, dan metode, yang semuanya disebut dengan prosedur (Alexander, dkk., 1991; Anderson, 1983; deJong dan Ferguson-Hessler, 1996). Pengetahuan prosedural berkaitan dengan pertanyaan "bagaimana". Pengetahuan prosedural ini terbagi menjadi tiga subjenis yaitu: (1) pengetahuan tentang keterampilan dalam bidang tertentu dan algoritma; (2) pengetahuan tentang teknik dan metode dalam bidang tertentu; dan (3) pengetahuan tentang kriteria untuk menentukan kapan harus menggunakan prosedur yang tepat.

Pengetahuan metakognitif merupakan dimensi baru dalam taksonomi revisi. Pencantuman pengetahuan metakognitif dalam kategori dimensi pengetahuan dilandasi oleh hasil penelitian-penelitian terbaru tentang peran penting pengetahuan siswa mengenai kognisi mereka sendiri dan kontrol mereka atas kognisi itu dalam aktivitas belajar (Bransford, dkk.,1999; Zimmerman dan Schunk, 1998).

Pengetahuan metakognitif terbagi menjadi tiga subjenis yaitu: (1) pengetahuan strategis; (2) pengetahuan tentang tugas-tugas kognitif yang meliputi pengetahuan kontekstual dan kondisional; dan (3) pengetahuan diri. 
Pengetahuan strategis adalah pengetahuan tentang strategi-strategi belajar/ berpikir/ pemecahan masalah. Strategi pengulangan berupa mengulang-ulang kata-kata atau istilah-istilah untuk memberikan ingatan. Strategi elaborasi menggunakan berbagai teknik merangkum, memparafrase, dan memilih gagasan pokok dalam teks. Strategi pengorganisasian adalah membuat garis besar materi pelajaran, membuat pemetaan konsep, dan membuat catatan. Pengetahuan tentang tugas- tugas kognitif yang meliputi pengetahuan kontekstual dan kondisional.

Flavell (1979) menyatakan bahwa pengetahuan metakognitif mencakup pengetahuan yang berhubungan dengan berbagai tugas kognitif yang sulit dan memerlukan sistem kognitif dan strategi-strategi kognitif.

Selain mengetahui strategi belajar dan berpikir, juga memerlukan pengetahuan kondisional yaitu siswa harus tahu kapan dan mengapa menggunakan strategi-strategi tersebut dengan tepat (Paris, dkk., 1983). Flavel (1979) mengemukakan bahwa selain pengetahuan tentang beragam strategi dan tugas kognitif, pengetahuan diri juga merupakan komponen yang penting dalam metakognitif. Pengetahuan diri mencakup pengetahuan tentang kekuatan, kelemahan, minat, bakat, motivasi dalam kaitannya dengan kognisi dan belajar. Dimensi proses kognitif dalam taksonomi revisi terbagi menjadi 6 kategori yaitu: mengingat, memahami, mengaplikasikan, menganalisis, mengevaluasi, dan mencipta. Kategori-kategori tersebut akan dijelaskan dalam Tabel Kategori Taksonomi Anderson dan Kratwohl pada Tabel 2.

Tabel 2 Kategori Taksonomi Anderson dan Kratwohl

\begin{tabular}{|c|c|c|}
\hline $\begin{array}{l}\text { Kategori dan } \\
\text { Proses Kognitif }\end{array}$ & Nama Lain & Definisi dan Contoh \\
\hline \multicolumn{3}{|c|}{ 1. Mengingat : Mengambil pengetahuan dari memori jangka panjang } \\
\hline 1.1 Mengenali & Mengidentifikasi & $\begin{array}{l}\text { Menempatkan pengetahuan dalam } \\
\text { memori jangka panjang yang sesuai } \\
\text { dengan pengetahuan tersebut (misalnya, } \\
\text { mengenali tanggal terjadinya peristiwa } \\
\text { penting dalam sejarah Indonesia) }\end{array}$ \\
\hline $\begin{array}{l}\text { 1.2 Mengingat } \\
\text { kembali }\end{array}$ & Mengambil & $\begin{array}{l}\text { Mengambil pengetahuan yang relevan } \\
\text { dari memori jangka panjang (misalnya } \\
\text { mengingat kembali tanggal peristiwa- } \\
\text { peristiwa penting dalam sejarah } \\
\text { Indonesia) }\end{array}$ \\
\hline \multicolumn{3}{|c|}{$\begin{array}{l}\text { 2. Memahami : Mengkonstruksi makna dari materi pembelajaran, termasuk apa } \\
\text { yang diucapkan, ditulis, dan digambar oleh guru }\end{array}$} \\
\hline 2.1 Menafsirkan & $\begin{array}{l}\text { Mengklarifikasikan } \\
\text { Memparafrasekan } \\
\text { Mempresentasi } \\
\text { Menerjemahkan }\end{array}$ & $\begin{array}{l}\text { Mengubah satu bentuk gambaran } \\
\text { (misalnya angka) jadi bentuk lain } \\
\text { (misalnya kata-kata), (misalnya } \\
\text { memparafrasekan puisi menjadi } \\
\text { karangan bebas }\end{array}$ \\
\hline
\end{tabular}




\begin{tabular}{|c|c|c|}
\hline 2.2 Mencontohkan & $\begin{array}{l}\text { Mengilustrasikan } \\
\text { Memberi contoh }\end{array}$ & $\begin{array}{l}\text { Menemukan contoh atau ilustrasi tentang } \\
\text { konsep atau prinsip (misalnya memberi } \\
\text { contoh tentang aliran-aliran seni lukis) }\end{array}$ \\
\hline $\begin{array}{l}\text { 2.3 } \\
\text { Mengklasifikasi } \\
\text { kan }\end{array}$ & $\begin{array}{l}\text { Mengategorikan, } \\
\text { Mengelompokkan }\end{array}$ & $\begin{array}{l}\text { Menentukan sesuatu dalam satu kategori } \\
\text { (misalnya mengklasifikasikan hewan- } \\
\text { hewan bertulang belakang) }\end{array}$ \\
\hline 2.4 Merangkum & $\begin{array}{l}\text { Mengabstraksi } \\
\text { Menggeneralisasi }\end{array}$ & $\begin{array}{l}\text { Mengabstraksikan tema umum atau poin- } \\
\text { poin pokok } \\
\text { (misalnya menulis ringkasan pendek } \\
\text { tentang peristiwa-peristiwa yang } \\
\text { ditayangkan di televisi) }\end{array}$ \\
\hline 2.5 Menyimpulkan & $\begin{array}{l}\text { Menyarikan, } \\
\text { Mengesktrapolasi, } \\
\text { Menginterpolasi, } \\
\text { Memprediksi }\end{array}$ & $\begin{array}{l}\text { Membuat kesimpulan yang logis dari } \\
\text { informasi yang diterima (misalnya dalam } \\
\text { belajar bahasa Inggris, menyimpulkan } \\
\text { tata bahasa berdasarkan contohnya }\end{array}$ \\
\hline $\begin{array}{l}2.6 \\
\mathrm{n}\end{array}$ & $\begin{array}{l}\text { Mengontraskan, } \\
\text { Memetakan, } \\
\text { Mencocokkan }\end{array}$ & $\begin{array}{l}\text { Menentukan hubungan antara dua ide, } \\
\text { dua objek, dan semacamnya (misalnya, } \\
\text { membandingkan peristiwaperistiwa } \\
\text { sejarah dengan keadaan sekarang) }\end{array}$ \\
\hline 2.7 Menjelaskan & Membuat model & $\begin{array}{l}\text { Membuat model sebab - akibat dalam } \\
\text { sebuah sistem } \\
\text { (misalnya, menjelaskan sebab-sebab } \\
\text { terjadinya peristiwa-peristiwa penting } \\
\text { pada abad ke } 18 \text { di Indonesia }\end{array}$ \\
\hline
\end{tabular}

3. Mengaplikasikan : Menerapkan atau menggunakan suatu prosedur dalam keadaan tertentu

\begin{tabular}{lll}
\hline 3.1 Mengeksekusi & Melaksanakan & $\begin{array}{l}\text { Menerapkan gaya gravitasi dalam } \\
\text { kehidupan sehari-hari }\end{array}$ \\
\hline 3.2 Mengimplemen- & Menggunakan & Menerapkan suatu prosedur pada tugas \\
tasikan & $\begin{array}{l}\text { yang tidak familier (misalnya, } \\
\text { menggunakan Hukum Newton kedua } \\
\text { pada konteks yang tepat) }\end{array}$ \\
\hline
\end{tabular}

4. Menganalisis: Memecah-mecah materi jadi bagian-bagian penyusunnya dan menentukan hubungan-hubungan antar bagian itu dan hubungan antara bagian-bagian tersebut dengan keseluruhan struktur atau tujuan

\begin{tabular}{cll}
\hline 4.1 Membedakan & $\begin{array}{l}\text { Menyendirikan, } \\
\text { Memilah, } \\
\text { Memfokuskan, } \\
\text { Memilih }\end{array}$ & $\begin{array}{l}\text { Membedakan bagian materi pelajaran } \\
\text { yang relevan dan tidak relevan, } \\
\text { (membedakan antara bilangan prima dan } \\
\text { bukan bilangan prima dalam } \\
\text { matematika) }\end{array}$ \\
\hline 4.2 Mengorganisasi & $\begin{array}{c}\text { Menemukan } \\
\text { koherensi } \\
\text { Memadukan, } \\
\text { Membuat garis } \\
\text { besar, }\end{array}$ & $\begin{array}{l}\text { Menentukan bagaimana elemen-elemen } \\
\text { bekerja atau berfungsi dalam sebuah } \\
\text { struktur (misalnya, menyusun bukti-bukti } \\
\text { dalam cerita sejarah menjadi bukti-bukti }\end{array}$ \\
yang mendukung dan menentang suatu \\
\hline
\end{tabular}




\begin{tabular}{|c|c|c|}
\hline & $\begin{array}{l}\text { Mendeskripsikan } \\
\text { peran, } \\
\text { Menstrukturkan }\end{array}$ & penjelasan historis) \\
\hline $\begin{array}{l}\text { 4.3Mengklasifikasik } \\
\text { an }\end{array}$ & Mendekonstruksi & $\begin{array}{l}\text { Menentukan sudut pandang, bias, nilai, } \\
\text { atau maksud dibalik materi pelajaran } \\
\text { (misalnya menunjukkan sudut pandang } \\
\text { penulis suatu cerita berdasarkan latar } \\
\text { belakang pendidikan penulis tersebut) }\end{array}$ \\
\hline \multicolumn{3}{|c|}{ 5. Mengevaluasi: Mengambil keputusan berdasarkan kriteria atau standar } \\
\hline 5.1 Memeriksa & $\begin{array}{l}\text { Mengoordinasi, } \\
\text { Mendeteksi, } \\
\text { Memonitor, Menguji }\end{array}$ & $\begin{array}{l}\text { Menemukan kesalahan dalam suatu } \\
\text { proses atau produk; menemukan } \\
\text { efektivitas suatu prosedur yang sedang } \\
\text { dipraktikkan (misalnya memeriksa } \\
\text { apakah kesimpulan seseorang sesuai } \\
\text { dengan data-data pengamatan atau } \\
\text { tidak) }\end{array}$ \\
\hline 5.2 Mengkritik & Menilai & $\begin{array}{l}\text { Menemukan inkonsistensi antara suatu } \\
\text { produk dan kriteria eksternal; } \\
\text { menentukan apakah suatu produk } \\
\text { memiliki konsistensi eksternal, } \\
\text { menemukan ketepatan suatu prosedur } \\
\text { untuk menyelesaikan masalah (misalnya, } \\
\text { menentukan satu metode dari dua } \\
\text { metode untuk menyelesaikan suatu } \\
\text { masalah) }\end{array}$ \\
\hline \multicolumn{3}{|c|}{$\begin{array}{l}\text { 6. Mencipta: Memadukan bagian-bagian untuk membentuk sesuatu yang baru dan } \\
\text { koheren atau untuk membuat suatu produk yang orisinal }\end{array}$} \\
\hline 6.1 Merumuskan & Membuat hipotesis & $\begin{array}{l}\text { Membuat hipotesis-hipotesis berdasarkan } \\
\text { kriteria (misalnya membuat hipotesis } \\
\text { tentang sebab-sebab terjadinya gempa } \\
\text { bumi) }\end{array}$ \\
\hline 6.2 Merencanakan & Mendesain & $\begin{array}{l}\text { Merencanakan prosedur untuk } \\
\text { menyelesaikan suatu tugas (misalnya } \\
\text { merencanakan proposal penelitian } \\
\text { tentang topik sejarah Candi Borobudur) }\end{array}$ \\
\hline 6.3 Memproduksi & Mengonstruksi & $\begin{array}{l}\text { Menciptakan suatu produk (misalnya } \\
\text { membuat habitat untuk spesies tertentu } \\
\text { demi suatu tujuan) }\end{array}$ \\
\hline
\end{tabular}

Dalam pembelajaran materi Perencanaan dan Pengembangan tes hasil belajar pada Matakuliah Evaluasi Pembelajaran PAI menggunakan pendekatan Pembelajaran berbasis Masalah sebagai bagian metode pembelajaran berpusat pasa siswa, maka ditetapkan atribut kemampuan yang dilibatkan dalam kegiatan pembelajaran, antara lain; kerja tim, interaksi tim/ diskusi, dokumentasi, presentasi, dan pemecahan masalah.

Dengan mengintegrasikan berbagai atribut kemampuan tersebut dalam proses pembelajaran berbasis masalah diharapkan dapat 
mengoptimalkan/menyeimbangkan kompetensi antara kecerdasan intelektual, kecerdasan motorik, dan kecerdasan emosi. Proses perkembangan kompetensi tersebut diamati dan dinilai melalui tahapan siklus terhadap kemampuan/ pengetahuan factual, konseptual, procedural, dan metokognitif pada materi Perencanaan dan Pengembangan Tes Hasil Pembelajaran PAI.

Pengetahuan faktual merupakan pengetahuan berupa elemen-elemen dasar yang harus diketahui dalam mempelajaran materi Perencanaan dan Pengembangan tes hasil belajar dan menyelesaikan masalah di dalamnya. Elemen-elemen dasar ini dapat digunakan dalam menjelaskan, memahami, dan secara sistematis menata dan memahami materi pembelajaran. Pengetahuan konseptual mencakup pengetahuan tentang kategori, klasifikasi, dan hubungan antara dua atau lebih kategori tentang perencanaan dan pengembangan tes hasil pembelajaran PAI. Pengetahuan ini meliputi skema, model, mental, dan teori yang meliputi elemenelemen tentang klasifikasi dan kategori; prinsip dan generalisasi; dan teori, model, dan struktur dalam materi perencanaan dan pengembangan tes hasil pembelajaran PAI. Pengetahuan prosedural adalah pengetahuan tentang cara merencanakan dan mengembangkan tes hasil pembelajaran PAI. Pengetahuan metakognitif merupakan pengetahuan mengenai strategis dan tugas-tugas kognitif yang meliputi pengetahuan kontekstual dan kondisional, dan pengetahuan diri yang harus dilatih dalam Perencanaan dan Pengembangan Tes Hasil Pembelajaran PAI.

\section{Metode Penelitian}

Metode yang digunakan dalam penelitian ini adalah classroom action research. Metode ini digunakan sebagai bentuk tindak lanjut terhadap hasil (diagnosis) kegiatan pembelajaran yang berlangsung pada materi Perencanaan dan Pengembangan Tes Hasil Belajar matakuliah Evaluasi Pembelajaran PAI pada semester sebelumnya, maka penelitian ini dilakukan untuk mencari dasar pengetahuan praktis dalam rangka memperbaiki keadaan/ situasi yang dilakukan secara terbatas dalam suatu situasi atau keadaan yang sedang berlangsung. Dengan demikian dapat diharapkan untuk terjadinya pengembangan keterampilan baru atau cara atau pendekatan baru untuk memecahkan masalah dengan penerapan langsung dalam kegiatan pembelajaran. materi perencanaan dan pengembangan tes PAI.

Subjek penelitian ini ditujukan kepada mahasiswa Prodi PAI STAI AlAmin Dompu semester IV yang memprogramkan matakuliah Evaluasi Pembelajaran PAI.

Untuk menemukan mekanisme implementasi SCL dalam menguatkan proses kognitif melalui kegiatan pembelajaran pada materi perencanaan dan pengembangan tes pembelajaran PAI, maka langkah instruksional dilakukan dalam siklus (tahap; persiapan, penerapan dan observasi, refleksi) berulang. 
Dokumentasi data dilakukan menggunakan lembar pengamatan proses dan angket tanggapan mahasiswa. Data yang dikumpulkan berupa data deskriptif (diolah dengan statistik deskriptif).

\section{Hasil dan Pembahasan}

\section{Implementasi Pada Siklus I}

Hasil implementasi pengetahuan factual yang berhubungan dengan kegiatan pengantar/ persiapan pembelajaran yang menggunakan pendekatan berbasis masalah sebagai bagian SCL yang melibatkan kepercayaan diri, komunikasi lisan, kerjasama, berfikir kritis dan analitis, dan manajemen diri pada siklus 1 menunjukkan bahwa secara umum prasyarat pengetahuan factual mahasiswa yang mendukung SCL belum memuaskan karena masih lebih dari 25\% mahasiswa berada pada level kurang kemampuan mahasiswa berfifir kritis-analitis sekitar 75\% mahasiswa berada pada level kurang.

Hasil implementasi pengetahuan kegiatan perencanaan tes pada siklus 1 menunjukkan bahwa secara umum soft skills/ pengetahuan konseptual mahasiswa yang mendukung SCL yang melibatkan kerjasama, etos kerja, manajemen waktu, dan inovasi belum memuaskan karena lebih dari 15\% mahasiswa berada pada level kurang dan yang perlu perhatian lebih adalah kemampuan berinovasi dan berestetika karena sekitar $60 \%$ mahasiswa berada pada level kurang. Sebagian mahasiswa tidak mampu menghasilkan gagasan atau karya baru berdasarkan potensi diri dan kurang mempunyai perilaku yang mengarah kepada keindahan, kebersihan, dan keserasian.

Hasil implementasi kegiatan pengembangan tes siklus 1 menunjukkan bahwa secara umum soft skills mahasiswa yang mendukung SCL termasuk: berfikir kritis dan analitis, serta komunikasi belum memuaskan karena masih lebih dari $27 \%$ mahasiswa berada pada level kurang terlebih lagi pada kemampuan berfikir kritis-analitis yang mencapai lebih $40 \%$ mahasiswa berada pada level rendah. Sebagian mahasiswa dalam level rendah ini umumnya belum mampu memahami permasalahan dan alternatif penyelesaian dengan alur berfikir kritis dan analitis, hanya sekitar $15 \%$ mahasiswa yang mampu berfikir kritis dan analitis.

Hasil implementasi pengetahuan procedural yang berhubungan dengan perencanaan dan pengembangan tes hasil belajar pada siklus 1 menunjukkan bahwa secara umum soft skills mahasiswa yang mendukung SCL untuk kegiatan dokumentasi yang melibatkan: komunikasi tulis dan lisan, kepercayaan diri, manajemen waktu, kerjasama, berfikir kritis dan analitis, serta manajemen diri belum memuaskan karena masih lebih dari $14 \%$ mahasiswa berada pada level kurang, terutama kerjasama yang mencapai lebih 20\% mahasiswa masih berada dalam level cukup. Umumnya mahasiswa belum mempunyai kemampuan bekerja dan menyelesaikan pekerjaan secara tim.

\section{Implementasi Pada Siklus II}

Sebagai bagian persiapan untuk memperbaiki kekurangan pada siklus I, maka kegiatan selanjutnya telah dilakukan pengulang materi (yang 
ditandai belum dipahami secara memadai sebagai pengetahuan prasyarat). Kegiatan ini juga dilakukan penguatan tentang pengetahuan factual, konseptual, procedural, dan metakognitif yang diperlukan dalam pengembangan tes hasil belajar.

Hasil implementasi kegiatan pengantar/ persiapan pembelajaran yang menggunakan pendekatan berbasis masalah pada siklus 2 menunjukkan bahwa secara umum soft skills mahasiswa yang mendukung SCL yang yang melibatkan: kepercayaan diri, komunikasi lisan, kerjasama, berfikir kritis dan analitis, dan manajemen diri menunjukkan peningkatan dari hasil implementasi pada siklus 1 . Semua mahasiswa telah memiliki kemampuan berfikir kritis dan analitis yang menandai adanya kepercayaan diri, kemampuan komunikasi lisan, kerjasama, dan manajemen diri yang berada pada level baik atau tidak ada yang berada pada level cukup dan kurang. Terdapat sekitar 20\% mahasiswa yang mempunyai kemampuan kerjasama, berfikir kritis dan analitis, dan manajemen diri pada level sangat baik.

Hasil implementasi kegiatan pengembngan tes hasil belajar yang masuk ke dalam pengetahuan konseptual dan procedural pada siklus 2 menunjukkan bahwa secara umum soft skills mahasiswa yang mendukung SCL yang melibatkan: berfikir kritis dan analitis telah menunjukkan peningkatan dari hasil siklus 1. Sebagian besar mahasiswa (85\%) mempunyai kemampuan kerjasama, etos kerja, manajemen waktu, inovasi, dan berfikir kritis-analitis yang berada berada pada level baik. Di samping itu terdapat sekitar 15\% mahasiswa yang mempunyai kemampuan kerjasama dan komunikasi pada level sangat baik. Namun masih terdapat sekitar $4 \%$ mahasiswa yang mempunyai kemampuan berinovasi, berfikir kritis dan analitis pada level kurang.

Hasil implementasi kegiatan dokumentasi kegiatan persiapan dan pengembangan tes hasil belajar siklus 2 menunjukkan bahwa secara umum soft skills mahasiswa yang mendukung SCL yang yang melibatkan: berfikir kritis dan analitis, serta komunikasi tulis/dokumentasi, menunjukkan peningkatan yang berarti. Semua mahasiswa telah dikategorikan mampu berfikir kritis dan analitis, serta mendokumentasikan dengan baik hasil perencanaan dan pengembangan tes hasil belajar yang berada minimal pada level cukup (4\%), bahkan pada kemampuan berfikir kritis dan analitis serta kemampuan tulis terdapat $75 \%$ mahasiswa yang berada pada level sangat baik. Hasil pengamatan menunjukkan bahwa sebagian besar mahasiswa telah mampu memahami dan menemukan inti permasalahan dan alternatif penyelesaian dengan alur berfikir kritis-analitis, serta mempunyai kemampuan menyampaikan pendapat dan gagasan secara tertulis.

Hasil implementasi kegiatan yang melibatkan kemampuan kognitif (presentasi semua kegiatan yang dilakukan setiap tahap dan siklus) pada siklus 2 menunjukkan bahwa secara umum soft skills mahasiswa yang mendukung SCL untuk kegiatan presentasi yang melibatkan: komunikasi tulis dan lisan, kepercayaan diri, manajemen waktu, kerjasama, berfikir kritis dan analitis, dan manajemen diri telah menunjukkan peningkatan yang berarti. Umumnya mahasiswa telah mempunyai kemampuan yang berada pada level baik, bahkan kemampuan komunikasi tulis dan lisan, kemampuan 
berfikir kritis dan analitis terdapat 15\% mahasiswa yang berada pada level sangat baik.

\section{Kesimpulan dan Saran}

\section{Kesimpulan}

Berdasarkan hasil dan pembahasan diuraikan di atas, maka dapat disimpulkan beberapa hal sebagai berikut:

a. Teknik instruksional SCL khususnya pembelajaran berbasis masalah dapat diintegrasikan ke dalam kegiatan perencanaan dan pengembangan tes hasil belajar dengan melibatkan berbagai atribut yang dapat menguatkan proses kognitif seperti: kerja kelompok, diskusi, dokumentasi, presentasi, dan pemecahan masalah.

b. Atribut-atribut softs skills mahasiswa yang bersesuaian dengan atributatribut SCL yang diintegrasikan dalam proses kognitif mahasiswa pada kegiatan perencanaan dan pengembangan tes hasil belajar adalah: kerjasama, diskusi, kemampuan dokumentasi, presentasi, berfikir kritis dan analitis merupakan penekanan dari pemecahan pemecahan masalah.

c. Implementasi SCL dalam kegiatan perencanaan dan pengembangan tes hasil belajar berdampak pada penguatan proses kognitif mahasiswa dalam perencanaan dan pengembangan tes hasil belajar.

d. Implementasi SCL dalam dalam perencanaan dan pengembangan tes hasil belajar cukup efisien digunakan, karena mahasiswa mampu mengembangan kemampuan proses kognitif sebagai bagian pengetahuan metakognitf yang diperlukan dalam kegiatan pembelajaran bermakna.

Saran

Berdasarkan hasil yang diperoleh dari implikasi Pendekatan Student Centered Learning (SCL) melalui Pembelajaran Berbasis Masalah pada Materi Perencanaan dan Pengembangan Tes Hasil Belajar Pendidikan Agama Islam yang dapat meningkatkan kemampuan mahasiswa terutama penguatan proses kognitif mahasiswa, maka implikasi Pendekatan Student Centered Learning (SCL), khususnya pembelajaran berbasis masalah perlu dipertimbangkan sebagai teknik instruksional pada materi yang membutuhkan kemampuan proses kognitif. 


\section{Daftar Pustaka}

Abdullah Tsani, Evaluasi Pembelajaran Matematika. Surabaya : Fakultas Tarbiyah Pendidikan Matematika IAIN Sunan Ampel.

Alexander, P., Schallert, D., Hare, V. 1991. Coming to Terms: How Researcher in Learning and Literacy Talk about Knowledge. Review of Educational Research, 61: 315 - 343.

Anderson, L.W., dan Krathwohl, D.R. 2001. A Taxonomy for Learning, Teaching, and Assesing: A Revision of Bloom's Taxonomy of Educatioanl Objectives. New York: Addison Wesley Longman, Inc.

Anderson, L.W. 1983. The Architecture of Cognition. Cambridge: Harvard University Press.

Arikunto, S. 2009. Dasar-dasar Evaluasi Pendidikan.Jakarta : Bumi Aksara.

Baharudin, Esa Nurwahyuni. 2007. Teori Belajar dan Pembelajaran. Jogjakarta: Ar-Ruzz Media Group.

Bransford, J.D., Brown, A.L., dan Cooking, R.R. 1999. How People Learn: Brain, Mind, Experience, and School. Washington DC: National Academy Press

deJong, T., dan Ferguson-Hessler, M. 1996. Types and Qualities of Knowledge. Educational Psychologist, 31: 105 - 113.

Flavell, J. 1979. Metacognition and Cognitive Monitoring: A New Area of Cognitive Developmental Inquiry. American Psychologist, 34: 906 911.

Krathwohl, D.R. 2001. A Taxonomy for Learning, Teaching, and Assesing: A Revision of Bloom's Taxonomy of Educatioanl Objectives. New York: Addison Wesley Longman, Inc.

Martiis Yamin. 2005. Strategi Pembelajaran Berbasis Kompetensi. Ciputat: Gaung Persada Press.

Paris, S., Lipson, M., dan Wixson, K. 1983. Becoming a Strategic Reading. Contemporary Educational Psycilogy, 8: 293 - 316.

Tina Afiatin, 2009, Pembelajaran Berbasis Student Centered Learning. Tersedia pada http:/ / www. inparamet ric.com

Undang-Undang Nomor 20 Tahun 2003. Sistem Pendidikan Nasional.

Zimmerman, B.J., dan Schunk, D. H. 1998. Self Regulated Learning: from Teaching to Self Reflective Practice. New York: Guilford Press. 